\title{
BIODEGRADATION OF PULP SLUDGE BY Phanerochaete chrysosporium, Penicillium oxalicum AND Penicillium citrinum AFTER SIX MONTHS INCUBATION
}

\author{
Siti Wahyuningsih \\ Forest Plant Fibres Technology Research and Development Institute \\ Jl. Raya Bangkinang-Kuok Km.9, Bangkinang 28401 Postal Code 4/BKN-Riau, Indonesia
}

Received: 24 October 2018, Revised: 23 August 20019, Accepted: 28 October 2019

\begin{abstract}
BIODEGRADATION OF PULP SLUDGE BY Phanerochaete chrysosporium, Penicillium oxalicum and Penicillium citrinum AFTER SIX MONTHS INCUBATION. The rise of pulp and paper production due to market's demand will increase both main and secondary products of pulp. Secondary products such as pulp sludge have low economic value, but high environmental cost. Therefore, improved technology is needed to raise its value. This study aims to evaluate the ability of Phanerochaete chrysosporium, a combination of Penicillium citrinum and $P$. oxalicum and a mixture of those three fungal species in decomposing pulp sludge after one and six months incubation. The pulp sludge was collected from pulp company in North Sumatera, Indonesia and it was pre-treated prior to composting. The composting was conducted by inoculating $P$. chrysosporium, a combination of P. oxalicum and P. citrinum or a mixture of those fungal species with a density of 107 spores/ $\mathrm{ml}$ into $15 \mathrm{~kg}$ treated sludge. The inoculated sludge was then incubated for one and six months. Analysis was held for the non-inoculated and inoculated sludge regarding $\mathrm{pH}$, cation exchange capacity (CEC) (me/100 g), macronutrients (N, P, K, Ca and $\mathrm{Mg})(\%)$, micronutrients (, $\mathrm{Zn})(\mathrm{ppm})$ and heavy metals $(\mathrm{Pb}, \mathrm{Cd})(\mathrm{ppm})$. After one month incubation, $P$. chrysosporium was leading in enhancing sludge's macro and micronutrients. After six months incubation, a combination of P. oxalicum and P. citrinum generated higher P, K, CEC and reduced lead content of the sludge. Meanwhile, a mixture of the three fungus species produced the highest $\mathrm{N}$ and $\mathrm{Mg}$.
\end{abstract}

Keywords: Pulp sludge, decomposition, P. chrysosporium, P. oxalicum, P. citrinum

BIODEGRADASI PULP SLUDGE DENGAN Phanerochaete chrysosporium, Penicillium oxalicum $D A N$ Penicillium citrinum SETELAH MASA INKUBASI ENAM BULAN. Meningkatnya produksi pulp dan kertas sebagai imbas kenaikan permintaan pasar akan menghasilkan komoditas dan juga hasil sampingan. Hasil sampingan berupa limbah pulp yang memiliki nilai ekonomi rendah dengan nilai konsekuensi lingkungan yang tinggi. Oleh karenanya, diperlukan teknologi untuk menambah nilai limbah pulp. Penelitian ini bertujuan untuk mengetahui

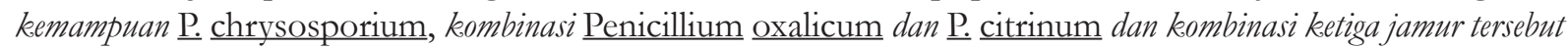
dalam mendekomposisi limbah pulp. Limbah pulp yang digunakan berasal dari perusahaan pulp di Sumatera Utara dengan perlakuan pendahuluan sebelum pengomposan. Pengomposan dilakukan dengan menginokulasi jamur $\underline{\mathrm{P}}$. chrysosporium, kombinasi P. oxalicum dan P. citrinum dan kombinasi dari ketiga jamur tersebut dengan kerapatan 107 (spora/ ml) ke dalam $15 \mathrm{~kg}$ limbah yang telah mendapat perlakuan awal. Kemudian, limbah yang telah diinokulasi tersebut diinkubasi selama satu dan enam bulan. Analisis dilakukan terbadap limbah yang tidak diinokulasi dan yang diinokulasi, terdiri dari analisa $p H$, cation exchange capacity (CEC) (me/100 g), hara makro (N, P, K, Ca and Mg)(\%), hara miro (S, Zn) $(\not p m)$ and logam berat $(\mathrm{Pb}, \mathrm{Cd})(\not p m)$. Setelah satu bulan inkubasi, $\underline{\mathrm{P}}$ chrysosporium dapat meningkatkan hara makro

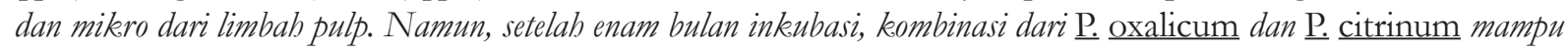
meningkatkan kadar P, K, CEC dan mengurangi kadar timbal dari limbah pulp. Sedangkan, kombinasi dari ketiga jamur $\underline{\mathrm{P}}$ oxalicum, $\underline{\mathrm{P}}$ citrinum and $\underline{\mathrm{P}}$ chrysosporium memberikan kadar $\mathrm{N}$ dan $\mathrm{Mg}$ tertinggi.

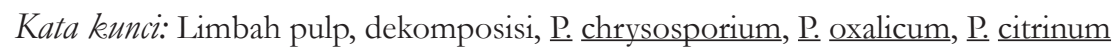

*Corresponding author: sitiwahyuningsih02@gmail.com 


\section{INTRODUCTION}

Currently, pulp and paper industries in Indonesia rank among the top 20 producers in the world, ranks as tenth for pulp and sixth for paper (APKI, 2016). Meanwhile, world's demand for the products increases $2-3 \%$ every year which drives Indonesia's pulp and paper industries to increase capacity from 7.93 million tons per year to 10.53 million tons (Setyawati, 2017). The increasing capacity will also generate secondary products in a large quantity such as wastewater sludge, wood yard wastes, causticizing wastes, and ashes (Simao, Hotza, Raupp-Pereira, Labrincha, \& Montedo, 2018). It is estimated that one tonne paper production generates 40 to 50 tonne sludge (dry), consisting of $70 \%$ primary sludge and $30 \%$ secondary sludge (Bajpai, 2015). The sludge contains 59$72 \%$ (dry basis) cellulose, 6-16\% lignin, 7-10 $\%$ hemicellulose, $10-70 \%$ ash, and inorganic contents such as kaolin clay, calcium carbonate, titanium dioxide (Das, Tollner, \& Tornabene, 1998).

Many studies on composting pulp and paper's sludge were undertaken to give an added value to the disposal (Gopinathan \& Thirumurthy, 2012; Hazarika \& Khwairakpam, 2018; Rodriguez, de Castro Andrade, Bellote, \& Tomazello-Filho, 2018). However, its high $\mathrm{C} / \mathrm{N}$ ratio, low nutrients characteristic, and heavy metal content need to be addressed to use it as a soil amendment. Pulp and paper sludge decomposition can be raised by adding N fertilizer (N’Dayegamiye, Nyiraneza, Giroux, Grenier, \& Drapeau, 2013), manure (Hazarika \& Khwairakpam, 2018) or decomposer (Hong, Dashtban, Chen, Song, \& Qin, 2015). In 2005, it was reported that 25 mills in the US recycled their wastewater treatment's sludge and deinking residual as compost by using windrow method (Bird \& Talberth, 2008). However, in the composting process by those mills was not mentioned the use of decomposers.

Some fungi species can produce cellulose degrading enzyme (Morgenstern \& Powlowski, 2014). Among many fungi species, white rot fungi is a well-known lignocellulosic degrading fungus by producing LiP, MnP and Lcc (Rajwar, Joshi, \& Rai, 2016). Phanerochaete chrysosporium, a white rot basidiomycete generates LiP and MnPs, enzymes for lignin degradation (Bak et al., 2009). Those lignin-degrading enzymes are produced under limited nutrient, particularly nitrogen (Tien \& Kirk, 1988). The MnP is the main enzyme for lignin degradation that using $\mathrm{H}_{2} \mathrm{O}_{2}$ to oxidize $\mathrm{Mn}^{2+}$ to $\mathrm{Mn}^{3+}$ (Wang, Yao, \& Su, 2018). Stimulation of $\mathrm{MnP}$ activity triggered by oxalic acid which the oxidation of glyoxylate and oxalate produce $\mathrm{H}_{2} \mathrm{O}_{2}$ (Kersten \& Cullen, 2007). P. chrysosporium also has a capability to degrade cellulose by producing cellulose-degrading enzymes: endoglucanase, cellobiohydrolases and exocellulases (Dashtban, Schraft, \& Qin, 2009). Those enzymes work synergistically to release cellobiose which by B-glucosidases will be converted to glucose (Horn, Vaaje-kolstad, Westereng, \& Eijsink, 2012).

Penicillium oxalicum and Penicillium citrinum have also been known to have generated b-glucanase (Doughari, 2011). However, P. oxalicum will generate more lignocellulose enzymes in complex substrates such as agricultural waste than in a pure cellulose medium (Liao, Li, Wei, Shen, \& Xu, 2014). This phenomenon indicates P. oxalicum potential as cellulose producer for industrial purposes. Meanwhile, substrate alkali pre-treatment can induce CM Case production of P. oxalicum (Shah, Kalia, \& Patel, 2015), and lignin presence does not interrupt saccharification of lignocellulose materials. On the other hand, P. citrinum secretes LiP (Yadav, Yadav, \& Yadav, 2009) can generate thermophilic and acidophilic B-glucosidases in solid state fermentation of rice bran $(\mathrm{Ng}$ et al., 2010). However, cellulose generation of P. citrinum will be higher if no nitrogen source is added (Ghoshal, Banerjee, \& Shivhare, 2013). Utilization of $P$. citrinum in rice husks fermentation resulted in cellulose yields of 37 units/g in 12 days and the cellulose degraded more than 70\% (Kuhad \& Singh, 1993). 
Pulp sludge used in this study had a high $\mathrm{CN}$ ratio, about 62.7. Application of the sludge directly to the soil can cause $\mathrm{N}$ immobilisation. A common sludge composting method was mixing the sludge with manure or other rich nitrogen materials to lower the CN ratio (Gopinathan \& Thirumurthy, 2012; Quaye, Volk, \& Leopold, 2011). Microbes are usually applied to mill's wastewater for lignin decolourisation or detoxification (Hossain \& Ismail, 2015; Madan, Sachan, \& Singh, 2018). However, in a conventional composting, the use of decomposers has been widely practiced. This paper examines the ability of $P$. chrysosporium, a combination of $P$. oxalicum and $P$. citrinum and a mixture of those three fungal species in enhancing decomposition of pulp sludge generated from a pulp company located in North Sumatera, Indonesia.

\section{MATERIALS AND METHOD}

\section{A. Study Site}

The research was conducted at the Research and Development Institute of Fiber Technology of Forest Plant, Kampar, Riau. Decomposers isolation, multiplication and density counting were held in microbiology laboratory. Whereas the composting was performed in the technology laboratory.

\section{B. Methods}

Fresh pulp sludge was collected from a pulp company located in North Sumatera Province, Indonesia. The company employs kraft cycle for pulping wood chips. Chemicals for bleaching process was $\mathrm{ClO}_{2}, \mathrm{H}_{2} \mathrm{O}_{2}, \mathrm{CaO}$, oxygen, $\mathrm{HCl}, \mathrm{S}, \mathrm{NaOH} 10 \%, \mathrm{Na}_{2} \mathrm{SO}_{4}$, and $\mathrm{SO}_{2}$ (Simangunsong, 2014). The study showed that the $\mathrm{pH}$ of the pulp sludge was neutral (7.2). Sludge material sampling for study was taken from the top, middle and bottom of a pile. The sludge characteristics were wet, black, lumpy, and stinky and contained fibres and residues of the pulping process. Prior to composting, the sludge was pre-treated through dewatering. The sludge was air-dried to $60-70 \%$ moisture content for high composting-ability
(Malinska \& Zabochnicka-Swiatek, 2013). For composting, the dewatered sludge was not sterilized, weighed $15 \mathrm{~kg}$, put in a plastic bucket and placed in a composting site.

A medium for decomposers multiplication was potato dextrose agar (PDA). The medium was made by diluting $39 \mathrm{~g}$ commercial potato dextrose agar (Oxoid) in $1000 \mathrm{ml}$ sterile water. The agar medium sterilization was held using autoclave at $121^{\circ} \mathrm{C}, 15$ psi for 15 minutes. Meanwhile, for sterilization of laboratory instruments using autoclave was held for 30 minutes. Spores of decomposer were inoculated from a test tube into the sterilized PDA medium in an incubator. The inoculated medium was incubated in the dark at room temperature for a week.

$P$. oxalicum and $P$. citrinum were collected from a former study (Wahyuningsih, 2014). However, in the former study, the fungi had not yet been identified. The fungi identification was then held in the Indonesian Institute of Science, Bogor, Indonesia. The fungi were isolated from a rhizosphere of Acacia mangium and sludge of pulp and paper mill located in Riau Province, Indonesia. Soil samples of $A$. mangium's rhizosphere were collected from 10 $20 \mathrm{~cm}$ soil depth. Various serial dilutions of soil samples and pulp and paper sludge were plated on Potato Dextrose Agar and incubated at room temperature for 6 days. The fungal isolates were tested for their ability to degrade cellulose and lignin in CMC and Bavendam lignin 1\% medium. Meanwhile, the isolate of $P$. chrysosporium American Type Culture Collection (ATCC) 34541 was obtained from Biotechnology Centre, Gadjah Mada University, Yogyakarta, Indonesia. Each fungus species was maintained in test tubes containing potato dextrose agar and stored at $\pm 40^{\circ} \mathrm{C}$.

For composting, spores of $P$. chrysosporium, $P$. oxalicum and $P$. citrinum single inoculant were harvested from the agar medium surfaces. The spores, either single fungus species or a mixture of two or three species were diluted in $150 \mathrm{ml}$ sterile water and counted with a haemocytometer to reach inoculum density at 
$10^{7}$ (spora $\mathrm{ml}^{-1}$ ). The density was determined based on a former study that compared to the density of P. oxalicum, P. citrinum and a mixture of both fungi at $107,10^{8}$ and $10^{9}$ (spora ml $\left.{ }^{1}\right)$ as pulp and paper sludge's decomposers. The result showed pulp and paper's sludge inoculated with a mixture of $P$. oxalicum and $P$. citrinum at a density of 107 (spora $\mathrm{ml}^{-1}$ ) had the highest cation exchange capacity.

The composting was held by inoculating decomposers consisting of; P. chrysosporium, a combination of $P$. citrinum and $P$. oxalicum, and a mixture of $P$. chrysosporium, $P$. citrinum and $P$. oxalicum into the sludge. For control, the sludge was not inoculated with any decomposers. Sterile water $(150 \mathrm{ml})$ contained inoculums was poured into $15 \mathrm{~kg}$ dewatered pulp sludge placed in a bucket. Each treatment was replicated three times. The top of the bucket was covered by a clear plastic sheet to avoid flies. During composting, sterile water was sprayed to the incubated sludge to maintain the moisture. Laboratory analysis was held after one and six month's incubation. The analysis was undertaken for composite samples of each treatment. The composite samples were analysed for its macronutrients $(\mathrm{N}, \mathrm{P}, \mathrm{K}, \mathrm{Ca}$, $\mathrm{Mg})$, micronutrients $(\mathrm{S}, \mathrm{Zn})$ and heavy metals $(\mathrm{Pb}, \mathrm{Cd}, \mathrm{As}, \mathrm{Hg})$. The first and sixth months sampling aim to know the inoculums ability in degrading organic matter of the sludge through time.

\section{Analysis}

Laboratory analysis was undertaken based on organic fertilizer analysis ((Evianti \& Sulaeman, 2009). The analysis was to determine the $\mathrm{pH}$, CEC (me/100 g), organic C (\%), macronutrients $(\mathrm{N}, \mathrm{P}, \mathrm{K}, \mathrm{Ca}, \mathrm{Mg})(\%)$, micronutrients $(\mathrm{S}, \mathrm{Zn})$ (ppm) and heavy metals ( $\mathrm{Pb}, \mathrm{Cd})(\mathrm{ppm})$ content of the non-inoculated and inoculated sludge. Sample preparation was prepared by grinding and sieving the sludge using $2 \mathrm{~mm}$ sieve before analysis. $\mathrm{pH}$ measurement was conducted by diluting $10 \mathrm{~g}$ prepared sludge in $50 \mathrm{ml}$ sterile water in a test tube and centrifuging for 30 minutes. The sludge suspension was measured for $\mathrm{pH}$ and $\mathrm{CEC}$ (me/100 g). The organic C (\%) was determined using the Walkley and Black method. The total N (\%) was determined by using the Kjeldahl method. $\mathrm{P}_{2} \mathrm{O}_{5}(\%)$ and S (\%) were determined using a spectrophotometer. Determination of $\mathrm{K}_{2} \mathrm{O}_{5}(\%), \mathrm{Ca}(\%), \mathrm{Mg}$ (\%), $\mathrm{Zn}$ (ppm), $\mathrm{Pb}$ (ppm) and $\mathrm{Cd}$ (ppm) were determined using atomic absorption spectrophotometer. These parameters were analysed to know the ability of $P$. citrinum, $P$. oxalicum, and $P$. chrysosporium to increase sludge's macro and micronutrients. Moreover, pulp sludge does not only contain organic waste, but also calcium carbonate, kaolinite and talc (Abdullah, Ishak, Kadir, \& Bakar, 2015). The decomposers inoculated to the pulp sludge were expected to raise the macro and micronutrients and reduce the heavy metal contents.

\section{RESULT AND DISCUSSION}

Pulp sludge inoculated with the fungi contained higher macro and micronutrients and lower heavy metals than the non-inoculated pulp sludge. In one month incubation, macronutrients $(\mathrm{N}, \mathrm{P}$, and $\mathrm{Mg})$ of the inoculated sludge have increased (Table 1). However, CEC of the non-inoculated sludge was higher than the inoculated, particularly because of the high percentage of calcium and potassium. The high calcium and potassium content of the sludge is related to metal removal process during pulping to prevent operating problems (Maples \& Ambady, 1991).

Those metals are originating from the wood supply. However, during pulping, calcium oxide $(\mathrm{CaO})$ are also added in a re-causticizing step to increase $\mathrm{NaOH}$ level (Simangunsong, 2014), which can increase the calcium level of the sludge. In one month incubation, sludge was inoculated with a combination of $P$. citrinum and P. oxalicum had the lowest $\mathrm{CN}$ ratio. However, the sludge's macronutrients $(\mathrm{P}, \mathrm{K}, \mathrm{Ca}$ and $\mathrm{Mg}$ ) increased when the sludge was inoculated with P. chrysosporium. Further, a study by Zhang et al. (2018) showed P. chrysosporium decreased $30 \%$ of the total organic matter of sewage 
Table 1. Chemical and macronutrients analysis of pulp sludge after incubated for a month

\begin{tabular}{|c|c|c|c|c|c|c|c|c|c|}
\hline Inoculum & $\mathrm{pH}$ & $\begin{array}{c}\text { Org } \\
\text { C } \\
(\%)\end{array}$ & $\begin{array}{c}\text { Total } \\
\mathrm{N} \\
(\%)\end{array}$ & $\begin{array}{l}\mathrm{C} / \mathrm{N} \\
\text { ratio }\end{array}$ & $\begin{array}{c}\mathrm{P}_{2} \mathrm{O}_{5} \\
(\%)\end{array}$ & $\begin{array}{l}\mathrm{K}_{2} \mathrm{O} \\
(\%)\end{array}$ & $\begin{array}{l}\mathrm{Ca} \\
(\%)\end{array}$ & $\begin{array}{l}\mathrm{Mg} \\
(\%)\end{array}$ & $\begin{array}{c}\text { CEC } \\
\mathrm{me} / 100 \mathrm{~g}\end{array}$ \\
\hline Without inoculum & 7.2 & 39.52 & 0.63 & 62.7 & 0.26 & 1.62 & 0.39 & 0.21 & 47.33 \\
\hline P. chrysosporium & 6.8 & 46.27 & 1.04 & 44.5 & 1.13 & 1.13 & 0.31 & 0.31 & 46.28 \\
\hline $\begin{array}{l}\text { P. oxalicum }+ \text { P. citrinum } \\
\text { P. chrysosporium }+P . \text { oxalicum }\end{array}$ & 6.7 & 43.85 & 1.09 & 40.2 & 1.08 & 1.08 & 0.26 & 0.29 & 46.81 \\
\hline+ P. citrinum & 6.9 & 46.58 & 1.11 & 42 & 1.05 & 1.05 & 0.28 & 0.28 & 47.14 \\
\hline
\end{tabular}

Table 2. Micronutrients and heavy metals content of pulp sludge after incubated for a month

\begin{tabular}{lcccc}
\hline \multirow{2}{*}{ Inoculum } & \multicolumn{2}{c}{ Micronutrients } & \multicolumn{2}{c}{ Heavy metals } \\
& $\mathrm{S}$ & Zinc & $\mathrm{Pb}$ & $\mathrm{Cd}$ \\
& $\mathrm{ppm}$ & $\mathrm{ppm}$ & $\mathrm{ppm}$ & $\mathrm{ppm}$ \\
\hline Without inoculum & 137.4 & 26.3 & 4.8 & 2.6 \\
P. chrysosporium & 164.1 & 388.2 & 1.4 & 1 \\
P. oxalicum + P. citrinum & 162.8 & 360.4 & 1.1 & 0.9 \\
P. chrysosporium + P. oxalicum + P. citrinum & 155.9 & 349.6 & 1.3 & 1.1 \\
\hline
\end{tabular}

sludge after 60 days incubation. According to Jeffries et al. (1981), a ligninolytic activity of P. chrysosporium depends on the availability of carbohydrate, nitrogen and sulphur. Further more, it was mentioned that to produce one $\mathrm{mg}$ of mycelial weight (dry) of P. chrysosporium requires $2.2 \mathrm{mg}$ carbohydrate, $5.4 \mu \mathrm{g}$ nitrogen and $0.5 \mu \mathrm{g}$ sulphur. Pulp sludge used in this study provided those nutrients sufficiently. On the other hand, Choudary et al. (2016) found that $P$. oxalicum decomposed $18 \%$ of $10 \mathrm{~g} / \mathrm{l}$ of a mixture of rice and wheat straw in a Mendel and Weber medium after 10 days incubation. While, Islam and Borthakur (2016) reported $P$. citrinum degraded $23.27 \%$ of rice stubble after 60 days incubation. A lower nutrients content of the sludge inoculated with Penicillium sp. in this study could be caused by the fungi consumption.

Meanwhile, the zinc content of the inoculated pulp sludge and incubated for a month increased about 13 times than the noninoculated (Table 2). Zinc in the pulp sludge can be sourced from wood and chemicals during the bleaching. Zinc content of Eucalyptus wood was reportedly linear with the zinc content in soil (Assareh, Shariat, \& Ghamari-Zare, 2008). Also, a mix of zinc dust and sulphuric acid are added during the bleaching process of mechanical pulp (Mall, 2014). On the other hand, production of metal chelator by fungus, namely oxalate, increases the immobilization of zinc of the pulp sludge. The accumulation of zinc in fungus biomass raised zinc content of the pulp sludge when the biomass was also extracted during micronutrients analysis. Among three inoculums used in this study, inoculation of $P$. chrysosporium enhanced zinc content of the sludge. The ability of $P$. chrysosporium to accumulate zinc is also shown in a study by Zhang et al. (2018). Except P. chrysosporium generates oxalate (Huang et al., 2015), it also has a high biosorption ability for $\mathrm{Zn}$ (II) and $\mathrm{Pb}$ (II) in which the uptake and yield are in an opposite position (Marandi, Ardejani, \& Afshar, 2010).

In a month's incubation, the inoculated sludge also showed lower level of lead and cadmium than the non-inoculated (Table 2). A combination of $P$. citrinum and $P$. oxalicum can 
reduce sludge's lead and cadmium content by about $77 \%$ and $65 \%$, respectively.

According to Mahish et al. (2018), lead biosorption of $P$. oxalicum in the leadcontaminated soil after nine days incubation was $56.35 \%$. Meanwhile, the dead biomass can absorb lead by $2.65 \mathrm{mg} \mathrm{g}^{-1}$ biomass. Tian et al. (2018) reported P. oxalicum can reduce lead up to $98 \%$ cation when innoculated to a media containing $1700 \mathrm{mg} / \mathrm{l} \mathrm{lead} \mathrm{and} \mathrm{fluoro} \mathrm{apatite.} P$. citrinum also has an ability to absorb lead as an insoluble lead in the matrix fungal mycelia which the process initiated through surface binding (Wahab, Adeyemi, Awang, Azham, \& Tay, 2017). For cadmium, $P$. oxalicum was reported resistant up to a concentration of $250 \mathrm{ppm}$ (Bahobil, Bayoumi, \& Atta, 2017). While at $\mathrm{pH}$ 6, P. citrinum can absorb cadmium of $0.25 \mathrm{~g} / 50 \mathrm{ml}$ through free biomass and $0.1 \mathrm{~g} / 50 \mathrm{ml}$ through immobilization (Suhag, 2011). A reduction of heavy metals content of material by a fungus is related to the production of organic acids such as citric and gluconate through precipitation or leaching (Gholami, Borghei, \& Mousavi, 2011; Xu, Ramanathan, \& Ting, 2014).

In comparison to pulp sludge that was inoculated and incubated for a month, the six months incubation resulted in higher macro and micronutrients (Table 3 and 4). The $\mathrm{pH}$ was also higher than that of one month incubation, probably it is related to a decreasing fungus activity. When less organic acids were produced by the fungus, the environment tends to have a higher $\mathrm{pH}$. The changes also occurred in $P$. chrysosporium performance. Although at one- month incubation P. chrysosporium generated higher phosphor and potassium contents of the sludge than other inoculums, after six months incubation, a combination of $P$. citrinum and $P$. oxalicum resulted in the highest values. It indicates that $P$. chrysosporium has a more rapid initial growth than another inoculum which also showed by a $\mathrm{pH}$ drop. Urek and Pazarlioglu (2007) found that the $\mathrm{MnP}$ activity of $P$. chrysosporium in a growing medium enriched with $\left(\mathrm{NH}_{4}\right)_{2} \mathrm{SO}_{4}$ was optimum when a concentration of nitrogen was $20 \mathrm{mM}$ or equal to $0.07 \%$. In this study, the sludge content of total nitrogen $\left(\left(\mathrm{NH}_{4}\right)_{2} \mathrm{SO}_{4}\right)$ and nitrogen was about $0.63 \%$ and $0.13 \%$, respectively. However, the abundance of sludge's nitrogen content can inhibit ligninolytic production of P. chrysosporium which also limits oxalic acid's secretion. Thus, along with incubation time, the increasing availability of nitrogen probably decreased LiP and MnP production.

A combination of $P$. citrinum and $P$. oxalicum showed rapid sludge decomposition in the six months incubation. A study by Waing et al. (2015) showed among 22 cellulolytic fungal species isolated from leaf litter, $P$. citrinum generated the largest clear zone in a CMC agar. While, in the same medium, $P$. oxalicum produced a smaller diameter of the clear zone. The clear zone in a CMC medium showed the ability of fungal species to decompose cellulosic materials. The sludge inoculated with these fungus combinations also resulted in higher phosphorous and potassium contents which the latter contributes to the increasing CEC.

Table 3. Chemical and macronutrients analysis of pulp sludge after incubated for six months

\begin{tabular}{|c|c|c|c|c|c|c|c|c|c|}
\hline Inoculum & $\mathrm{pH}$ & $\begin{array}{c}\text { Org } \\
\text { C } \\
(\%)\end{array}$ & $\begin{array}{c}\text { Total } \\
\mathrm{N} \\
(\%)\end{array}$ & $\begin{array}{l}\mathrm{C} / \mathrm{N} \\
\text { ratio }\end{array}$ & $\begin{array}{l}\mathrm{P}_{2} \mathrm{O}_{5} \\
(\%)\end{array}$ & $\begin{array}{l}\mathrm{K}_{2} \mathrm{O} \\
(\%)\end{array}$ & $\begin{array}{l}\mathrm{Ca} \\
(\%)\end{array}$ & $\begin{array}{l}\mathrm{Mg} \\
(\%)\end{array}$ & $\begin{array}{c}\text { CEC } \\
\text { me/100 g }\end{array}$ \\
\hline Without inoculum & 7.2 & 39.52 & 0.63 & 62.7 & 0.26 & 1.62 & 0.39 & 0.21 & 47.33 \\
\hline P. chrysosporium & 7.2 & 31.16 & 1.24 & 25.1 & 1.84 & 1.84 & 0.34 & 0.33 & 48.36 \\
\hline P. oxalicum + P. citrinum & 7.1 & 29.84 & 1.22 & 24.5 & 2.03 & 2.03 & 0.31 & 0.32 & 51.24 \\
\hline $\begin{array}{l}\text { P. chrysosporium + P. oxalicum } \\
+ \text { P. citrinum }\end{array}$ & 7.3 & 30.77 & 1.27 & 24.2 & 1.76 & 1.76 & 0.34 & 0.34 & 49.72 \\
\hline
\end{tabular}


Table 4. Micronutrients and heavy metals content of pulp sludge after incubated for six months

\begin{tabular}{lcccc}
\hline Inoculum & \multicolumn{2}{c}{ Micronutrients } & \multicolumn{2}{c}{ Heavy metals } \\
& $\begin{array}{c}\text { S } \\
(\mathrm{ppm})\end{array}$ & $\begin{array}{c}\text { Zinc } \\
(\mathrm{ppm})\end{array}$ & $\begin{array}{c}\text { Pb } \\
(\mathrm{ppm})\end{array}$ & $\begin{array}{c}\mathrm{Cd} \\
(\mathrm{ppm})\end{array}$ \\
\hline Without inoculum & 137 & 26.3 & 4.8 & 2.6 \\
P. chrysosporium & 173 & 391.2 & 1.3 & 0.9 \\
P. oxalicum + P. citrinum & 158 & 376.6 & 0.8 & 0.9 \\
P. chrysosporium + P. oxalicum + P. citrinum & 170 & 384.5 & 1 & 1 \\
\hline
\end{tabular}

A combination of $P$. oxalicum and $P$. citrinum also reduced the lead content from $1.1 \mathrm{ppm}$ to $0.8 \mathrm{ppm}$ after six months incubation. Wahab et al. (2017) found P. citrinum was optimum in absorbing lead when the concentration reached $400 \mathrm{ppm}$. According to this study, a longer incubation time probably can significantly reduce the sludge's lead content because the initial concentration was below $400 \mathrm{ppm}$. The study by Wahab et al. (2017) also reported that the older biomass age had lower metals biosorption capacity than the younger. During first-month incubation, a combination of $P$. citrinum and $P$. oxalicum showed slow lead biosorption activity which was probably the result of each species was adapting to another. Previous study shows, inoculation of $P$. citrinum alone or $P$. oxalicum alone did not significantly reduced heavy metals content $(\mathrm{Pb}$ and $\mathrm{Cd})$ of the sludge. However, P. oxalicum performed better in generating macro and micronutrients of the sludge than P. citrinum. Meanwhile, a combination of these Penicillium sp. increased macronutrients and decreased the heavy metals content $(\mathrm{Pb}$ and $\mathrm{Cd})$.

The ability of $P$. oxalicum and $P$. citrinum in producing organic acids, especially oxalic and citric acids can reduce heavy metals through mycelial binding (Abdel-ghany \& Abdelmongy, 2009). However, production of oxalic acid by $P$. citrinum is occurred at the last stage of growth and was suppressed in a media containing ammonium but increased by the presence of zinc (Sazanova et al., 2014). The pulp sludge that contains both ammonium and zinc can be suppressed and trigger the oxalic production of P. citrinum. However, as the oxalic acid is produced by $P$. citrinum at the last stage, a concentration of ammonium in the sludge will be reduced through consumption before the acid production.

In contrast to a combination of Penicillium sp., a mixture of Penicillium sp. with $P$. chrysosporium produced the highest nitrogen and magnesium content after six months incubation. High production of $\mathrm{N}$ and $\mathrm{Mg}$ could be mostly the contribution of P. chrysosporium. This study showed sludge inoculated with P. chrysosporium alone produced higher $\mathrm{N}$ and $\mathrm{Mg}$ than a combination of $P$. citrinum and $P$. oxalicum after six months incubation. Ligninolytic fungus, P. chrysosprium produces lignin degrading enzyme in a nitrogen-limited medium. Thus, to gain nitrogen, a ligninolytic fungus degrades $C$ organic and lignin in a poor nitrogen environment (Rinkes et al., 2016). Meanwhile, lead and cadmium content of the sludge after inoculation with a mixture of three fungi was remained higher than of Penicillium's combination. According to Akamatsu et al. (1990), oxidation of veratryl alcohol, an enzyme produced by P. chrysosporium, deteriorates oxalate to carbon dioxide but oxalate hinders the veratryl alcohol oxidation. Thus, a ligninolytic activity of $P$. chrysosporium could be inhibited by oxalate production from the fungi mixture. Also, metals removals of the sludge by the oxalic acid could be inhibited by the oxidation of vertaryl alcohol.

According to this study, the fungal isolates inoculated to the sludge can significantly decompose pulp sludge after six months of 
incubation. However, the $\mathrm{CN}$ ratio was still above 20. The increasing macronutrients after inoculation and incubation showed a better opportunity for the fungus as sludge decomposers. A reduction of heavy metal contents such as lead and cadmium after composting will also benefit to the environment. On the other hand, $P$. citrinum has been known to be able to chelate $\mathrm{Al}$ and $\mathrm{Fe}$ the application of which to acid soil or iron ore can raise phosphorous availability for plants (Rea, McSweeney, Dwyer, \& Bruckard, 2015). However, the use of decomposer for sludge composting in commercial scales are rarely found. The mills prefer to apply mechanical rather than biological composting (Bird \& Talberth, 2008). Mechanical composting by using a modern composting machine is commonly undertaken by adding nitrogen fertilizer, cow dung or other organic materials to raise compost quality. However, the Composting Council of Canada (2010) explained that mechanical composting by using in-vessel aerobic technology with a capacity 50,000 of tonne/year costs 300-500\$/tonne. Meanwhile, conventional composting using windrow technology at the same capacity costs 40-60\$/tonne.

\section{CONCLUSION}

A combination of $P$. citrinum and $P$. oxalicum is promising as decomposers for pulp sludge. They were better in generating nutrients and reducing the lead of the sludge after six months incubation. However, a longer incubation could be required to achieve $\mathrm{CN}$ ratio 20 . A combination of $P$. citrinum and $P$. oxalicum can be applied to sludge composting either in a mechanical or conventional composting. However, cost implication should be considered. The small sample size for chemical analysis was a limitation in this study. In the future, a study about the application of the non-inoculated and inoculated sludge to plants as soil amendment should be undertaken and a larger scale replication should be carried out to gain a statistically consistent result.

\section{ACKNOWLEDGEMENT}

I would like to express my sincere gratitude to the Ministry of Environment and Forestry for granted funding for the research. My sincere gratitude is also to Ramiduk Nainggolan, Minal Aminin, and Edi Nurrohman for their help during the research.

\section{REFERENCES}

Abdel-ghany, T. M., \& Abdel-mongy, M. (2009). Bioremoval of heavy metals in presence of oxalic and citric acid using Aspergillus Tamarii. The Egyptian Journal of Experimental Biology (Botany), 5(October), 53-58. doi://10.1016/j.ibiod.2014.11.001.

Abdullah, R., Ishak, C. F., Kadir, W. R., \& Bakar, R. A. (2015). Characterization and feasibility assessment of recycled paper mill sludges for land application in relation to the environment. International Journal of Environmental Research and Public Health. 12(8), 9314-9329. doi://10.3390/ijerph120809314.

Akamatsu, Y., Ma, D. B., Higuchi, T., \& Shimada, M. (1990). A novel enzymatic decarboxylation of oxalic acid by the lignin peroxidase system of white-rot fungus Phanerochaete chrysosporium. FEBS Letters (269)1, 261-263.

Asosiasi Pulp dan Kertas Indonesia. (2016). Opportunities and challenges of Indonesian pulp and paper industry. Jakarta, Indonesia.

Assareh, M. H., Shariat, A., \& Ghamari-Zare, A. (2008). Seedling response of three Eucalyptus species to copper and zinc toxic concentrations. Caspian Journal of Environmental Sciences, 6(2), 97-103.

Bahobil, A., Bayoumi, R. A., \& Atta, H. M. (2017). Fungal biosorption for cadmium and mercury heavy metal ions isolated from some polluted localities in KSA. International Journal of Current Microbiology and Applied Sciences, 6(6), 2138-2154.

Bajpai, P. (2015). Generation of waste in pulp and paper mills. In Management of Pulp and Paper Mill Waste (pp. 9-17). doi.://10.1007/978-3319-11788-1. 
Bak, J., Ko, J., Choi, I., Park, Y., Seo, J., \& Kim, K. (2009). Fungal pretreatment of lignocellulose by Phanerochaete chrysosporium to produce ethanol from rice straw. Biotechnology Bioengineering, 104(3), 471-482. doi://10.1002/bit.22423.

Bird, M., \& Talberth, J. (2008). Waste stream reduction and re-use in the pulp and paper sector: Project Task 5.1. Santa Fe: Center for Sustainable Economy, Washington State Department of Ecology Industrial Footprint Project.

Choudhary, M., Sharma, P. C., Jat, H. S., Nehra, V., McDonald, A. J., \& Garg, N. (2016). Crop residue degradation by fungi isolated from conservation agriculture fields under rice - wheat system of North-West India. International Journal of Recycling of Organic Waste in Agriculture, 5(4), 349-360. doi://10.1007/ s40093-016-0145-3.

Composting Councilof Canada. (2010). Composting processing technologies. Northumberland St, Toronto. Retrieved from http://www. compost.org/pdf/compost_proc_tech_eng. pdf on 1 Januari 2018.

Das, K. C., Tollner, E. W., \& Tornabene, T. G. (1998). Composting pulp and paper industry solid wastes: Process design and product evaluation. In Proceedings of the composting in the southeast conference and expo. University of Georgia, Athena.

Dashtban, M., Schraft, H., \& Qin, W. (2009). Fungal bioconversion of lignocellulosic residues; Opportunities and perspectives. International Journal of Biological Sciences, 5(6), 578-595.

Doughari, J. H. (2011). Production of $\beta$-glucanase enzyme from Penicillium oxalicum and Penicillium citrinum. African Journal of Biotehnology, 10(47), 9657-9660. doi://10.5897/AJB07.484.

Evianti, \& Sulaeman. (2009). Analisa kimia tanah, tanaman, pupuk dan air. In H. Prasetyo, B, D. Santoso, \& W. Ladiyani, R. (Eds.). Balai Penelitian Tanah, Bogor, Jawa Barat, Indonesia.

Gholami, R. M., Borghei, S. M., \& Mousavi, S. M. (2011). Fungal leaching of hazardous heavy metals from a spent hydrotreating catalyst. International Journal of Chemical and Molecular Engineering, 5(4), 362-367.

Ghoshal, G., Banerjee, U. C., \& Shivhare, U. S. (2013). Production using Penicillium citrinum
MTCC 9620 in solid state fermentation. British Biotechnology Journal, 3(4), 509-523.

Gopinathan, M., \& Thirumurthy, M. (2012). Evaluation of phytotoxicity for compost from organic fraction of municipal solid waste and paper and pulp mill sludge. Environmental Research, Engineering and Management, 59(1), 47-51.

Hazarika, J., \& Khwairakpam, M. (2018). Evaluation of biodegradation feasibility through rotary drum composting recalcitrant primary paper mill sludge. Waste Management, 76, 275-283.

Hong, Y., Dashtban, M., Chen, S., Song, R., \& Qin, W. (2015). Lignin in paper mill sludge is degraded by white-rot fungi in submerged fermentation. Journal of Microbial \& Biochemical Technology, 07(04), 177-181. doi://10.4172/1948-5948.1000201.

Horn, S. J., Vaaje-kolstad, G., Westereng, B., \& Eijsink, V. G. H. (2012). Novel enzymes for the degradation of cellulose Novel enzymes for the degradation of cellulose. Biotechnology Biofuels, 5, 45. doi://10.1186/1754-6834-545.

Hossain, K., \& Ismail, N. (2015). Bioremediation and detoxification of pulp and paper mill effluent: A review. Research Journal of Environmental Toxicology, 9(3), 113-134. doi://10.3923/rjet.2015.113.134.

Huang, D., Wang, C., Xu, P., Zeng, G., Lu, B., Li, N., ... Luo, X. (2015). A coupled photocatalyticbiological process for phenol degradation in the Phanerochaete chrysosporium-oxalate$\mathrm{Fe} 3 \mathrm{O} 4$ system. International Biodeterioration \& Biodegradation, 97, 115-123. doi://10.1016/j. ibiod.2014.11.001.

Islam, N., \& Borthakur, S. K. (2016). Study of fungi associated with decomposition of rice stubble and their role in degradation of lignin and holocellulose. Mycosphere, 2(6), 627-635. doi://10.5943/mycosphere/2/6/3.

Jeffries, T. W., Choi, S., \& Kirk, T. K. (1981). Nutritional regulation of lignin degradation by Phanerochaete chrysosporium. Applied and Environmental Microbiology, 42(2), 290-296.

Kersten, P., \& Cullen, D. (2007). Extracellular oxidative systems of the lignin-degrading basidiomycete Phanerochaete chrysosporium. Fungal Genetics and Biology, 44(2), 77-87. doi. org://10.1016/j.fgb.2006.07.007. 
Waing, Kristine Grace \& Abella, Evaristo \& Kalaw, Sofronio \& Waing, Frodie \& Galvez, Cecilia. (2015). Studies on biodiversity of leaf litter fungi of Central Luzon State University and evaluation of their enzyme producing ability. Current Research in Environmental \& Applied Mycology. 5. 269-276..

Kuhad, R. C., \& Singh, A. (1993). Enhanced production of cellulases by Penicillium citrinum in solid state fermentation of cellulosic residue. Worlds Journal of Microbiology and Biotechnology, 9(1), 100-101.

Liao, H., Li, S., Wei, Z., Shen, Q., \& Xu, Y. (2014). Insights into high-efficiency lignocellulolytic enzyme production by Penicillium oxalicum GZ-2 induced by a complex substrate. Biotechnology Biofuels, 7(162), 1-17.

Madan, S., Sachan, P., \& Singh, U. (2018). A review on bioremediation of pulp and paper mill effluent. An alternative to conventional remedial technologies. Journal of Applied and Natural Science, 10(1), 367-374.

Mahish, P. K., Tiwari, K. L., \& Jadhav, S. K. (2018). Biosorption of lead by biomass of resistant Penicillium oxalicum isolated from industrial effluent. Journal of Applied Sciences, 18(1), 41 47. doi://10.3923/jas.2018.41.47.

Malinska, K., \& Zabochnicka-Swiatek, M. (2013). Selection of bulking agents for composting of sewage sludge. Environment Protection Engineering, 39(2), 91-103. doi://10.5277/ EPE130209.

Mall, I. D. (2014). Pulp and paper; pulping and bleaching. Department of Chemical Engineering Indian Institute of Technology, Roorkee. Retrieved from https://nptel.ac.in/ courses/103107082/module3/lecture2/ lecture2.pdf on 1 January 2018.

Maples, G. E., \& Ambady, R. (1991). Process for recycling for bleach plant filtrate. US Grant; US5352332A.

Marandi, R., Ardejani, F. D., \& Afshar, H. A. (2010). Biosorption of lead (II) and zinc (II) ions by pre-treated biomass of phanerochaete chrysosporium. International Journal of Mining \& Environmental Issues, 1(1),9-16.

Morgenstern, I., \& Powlowski, J. (2014). Fungal cellulose degradation by oxidative enzymes: from dysfunctional GH61 family to powerful lytic polysaccharide monooxygenase family.
Briefings in Functional Genomics, 13(6), 471481. doi://10.1093/bfgp/elu032.

N'Dayegamiye, A., Nyiraneza, J., Giroux, M., Grenier, M., \& Drapeau, A. (2013). Manure and paper mill sludge application effects on potato yield, nitrogen efficiency and disease incidence. Agronomy, 3(1), 43-58. doi://10.3390/agronomy3010043.

Ng, I.-S., Li, C.-W., Chan, S.-P., Chir, J.-L., Chen, P. T., Tong, C.-G., ... Ho, T. D. (2010). High level production of a thermophilic b-glucosidase from $P$. citrinum YS40-5 by solid state fermentation with rice bran. Bioresource Technology, 101(4), 1310-1317. doi://10.1016/j.biortech.2009.08.049.

Pandey, A., Namrata, D., Kumar, B., Rinu, K. \& Trivedi, P (2008). Phosphate solubilization by Penicillium spp. isolated from soil samples of Indian Himalayan region. World Journal of Microbiology and Biotechnology, 24(1), 97-102. doi://10.1007/s11274-007-9444-1.

Quaye, A. K., Volk, T. A., \& Leopold, D. J. (2011). Impacts of Paper sludge and manure on soil and biomass production of willow. Biomass and Bioenergy, 35(7), 2796-2806. doi. org://10.1016/j.biombioe.2011.03.008.

Rajwar, D., Joshi, S., \& Rai, J. P. N. (2016). Ligninolytic enzymes production and decolorization potential of native fungi isolated from pulp and paper mill sludge key words. Nature Environmental and Pollution Technology, 15(4), 1241-1248.

Rea, S., McSweeney, N., Dwyer, R., \& Bruckard, W. (2015). Application of boechonolgy to iron ore beneficiation. In L. Lu (Ed.), Iron ore (p. 666). Cambridge: Woodhead Publishing.

Rinkes, Z. L., Bertrand, I., Ahmad, B., Amin, Z., Grandy, A. S., Wickings, K., \& Weintraub, M. N. (2016). Nitrogen alters microbial enzyme dynamics but not lignin chemistry during maize decomposition. Biogeochemistry, 128(1), 171-186. doi://10.1007/s10533-016-02010 .

Rodriguez, D. R. O., de Castro Andrade, G., Bellote, A. F. J., \& Tomazello-Filho, M. (2018). Effect of pulp and paper mill sludge on the development of 17-year-old loblolly pine (Pinus taeda L.) Forest Ecology and Management, 422, 179-189. 
Sazanova, K., Osmolovskaya, N., Schiparev, S., Yakkonen, K., Kuchaeva, L., \& Vlasov, D. (2015). Organic acids induce tolerance to zinc- and copper-exposed fungi under organic acids induce tolerance to zinc- and copper-exposed fungi under various growth conditions. Current Microbioly, 70(4), 520 527. doi://10.1007/s00284-014-0751-0.

Setyawati, A. (2017). Pulp and paper industry Indonesia: challenges and opportunities. Retrieved from https://www.indonesiainvestments.com/news/todays-headlines/ pulp-and-paper-industry-indonesiachallenges-and-opportunities/item 7738 ? on April 19, 2018.

Shah, S. P., Kalia, K. S., \& Patel, J. S. (2015). Optimization of cellulase production by Penicillium oxalicum using banana agrowaste as a substrate. The Journal of General and Applied Microbiology, 61(2), 35-43. doi://10.2323/ jgam.61.35.

Simangunsong, E. R. (2014). Pengendalian persediaan bahan baku kimia: Studi kasus di PT. Toba Pulp Lestari Tbk, Porsea, Sumatera Utara. (Bachelor Thesis). Bogor Agriculture University, Bogor.

Simao, L., Hotza, D., Raupp-Pereira, F., Labrincha, J. A., \& Montedo, O. R. K. (2018). Wastes from pulp and paper mills. A review of generation and recycling alternatives. Ceramica, 64(371), 443-453.

Sippola, J., Mäkelä-Kurtto, R., \& Rantala, P. R. (2003). Effect of composted pulp and paper industry wastewater treatment residuals on soil properties and cereal yield. Compost Science \& Utilization, 11(3), 228-237.

Suhag, M. (2011). Bio sorption of cadmium (II) from aqueous solutions by free and immobilized biomass of Penicillium citrinum. Journal of Advances in Science and Technology, 2(2), 1-5.

Tian, D., Wang, W., Su, M., Zheng, J., Wu, Y., Wang, S., \& Li, Z. (2018). Remediation of lead-contaminated water by geological fluorapatite and fungus Penicillium oxalicum. Environmental Science and Pollution Research, 25(21). doi://10.1007/s11356-018-2243-4.
Tien, M., \& Kirk, T. K. (1988). Lignin peroxidase of Phanerochaete chrysosporium. Methods in Ensymology, 161, 238-249.

Urek, R. O., \& Pazarlioglu, N. K. (2007). Enhanced production of manganese Phanerochaete chrysosporium peroxidase. Brazilian Archives of Biology and Technology, 50(6), 913-920.

Wahab, A. A., Adeyemi, F. M., Awang, A. S. A. H., Azham, Z., \& Tay, M. G. (2017). Biosorption of lead ( II ) ion using Penicillium citrinum KR706304 isolated from the mangrove soil environment of southeast Borneo. IFE Journal of Science, 19(2), 341-351. doi://10.4314/ijs.v19i2.14.

Wahyuningsih, S. (2014). Composting pulp and paper's sludge using fungal isolates. In Forestry research for sustainable forest management and community welfare, Proceedings of the $2^{\text {nd }}$ INAFOR August 27-28, 2013 (p. 994). Jakarta, Indonesia.

Wang, X., Yao, B., \& Su, X. (2018). Linking enzymatic oxidative degradation of lignin to organics detoxification. International Journal of Molecular Sciences, 19(11), 1-17. doi://10.3390/ijms19113373.

Xu, T., Ramanathan, T., \& Ting, Y. (2014). Bioleaching of incineration fly ash by Aspergillus niger - Precipitation of metallic salt crystals and morphological alteration of the fungus. Biotechnology Reports, 3, 8-14. doi://10.1016/j.btre.2014.05.009.

Yadav, M., Yadav, P., \& Yadav, K. (2009). Purification and characterization of lignin peroxidase from Loweporus lividus. Engineering in Life Sciences, 9(2), 124-129. doi://10.1002/ elsc.200800084.

Zhang, C., Xu, Y., Zhao, M., Rong, H., \& Zhang, K. (2018). Influence of inoculating white-rot fungi on organic matter transformations and mobility of heavy metals in sewage sludge based composting. Journal of Hazardous Materials, 344, 163-168. doi://10.1016/j. jhazmat.2017.10.017. 